\title{
Anti-Erythrocyte Allo-Immunization to Sickle Cell Disease Patients Followed in Transfusion Therapy Unit of the National Blood Transfusion Center of Abidjan Côte D'Ivoire
}

\author{
Sekongo Y. M. ${ }^{1,}$ " , Kouacou A. P. V. ${ }^{2}$, Kouamenan G. S. ${ }^{1}$, Kassogue K. ${ }^{1}$, Siransy-Bogui L. ${ }^{1,2}$, \\ N'Guessan P. ${ }^{1}$, Danho N. C. ${ }^{3}$, Yeboah O. R. ${ }^{2}$, Adou A. H. ${ }^{1}$, Dasse S. R. ${ }^{2}$, Konate S. ${ }^{1}$ \\ ${ }^{1}$ Therapeutic and Research Unit, National Blood Transfusion Center, Abidjan, Côte d'Ivoire \\ ${ }^{2}$ Immunology Service, University Hospital of Cocody, Abidjan, Côte d'Ivoire \\ ${ }^{3}$ Hematology Clinic, University Hospital of Yopougon, Abidjan, Côte d'Ivoire
}

Email address:

sekyass@yahoo.fr (Sekongo Y. M.)

${ }^{*}$ Corresponding author

\section{To cite this article:}

Kouacou A. P. V., Sekongo Y. M., Kouamenan G. S., Kassogue K., Siransy-Bogui L., N'Guessan P., Danho N. C., Y eboah O. R., Adou A. H., Dasse S. R., Konate S. Anti-Erythrocyte Allo-Immunization to Sickle Cell Disease Patients Followed in Transfusion Therapy Unit of the National Blood Transfusion Center of Abidjan Côte D'Ivoire. International Journal of Immunology. Vol. 5, No. 1, 2017, pp. 1-4. doi: 10.11648/j.iji.20170501.11

Received: December 5, 2016; Accepted: December 24, 2016; Published: January 25, 2017

\begin{abstract}
The objective of this study is to evaluate the frequency of post-transfusion anti-erythrocyte allo-immunization to sickle cell patients in order to propose strategies of optimal blood safety in Côted'Ivoire. It is a prospective study (January to December 2013) of patients with major sickle cell disease enrolled in the transfusion therapy unit of the National Blood Transfusion Center (CNTS)in Abidjan. The reed blood cells have been phenotyped and compatibilized by indirect Coombs test in the $\mathrm{ABO}$ and $\mathrm{Rh}$ Kel systems. The search for irregular antibodies was performed before each transfusion episode. The incidence of post-transfusion anti-erythrocyte allo-immunization to the sickle cell disease patients were high (12/42 or 28.6\%). We identified 14 allo-antibodies essentially anti-Rh specificity (12/14) with a high prevalence of anti-E allo-antibodies $(6 / 14)$ and anti-C (4/14). None anti-Kel antibodies was found. This study raises the risk of allo-immunization in non-phenotyped and non-compatibilized transfusions, especially in sickle cell multitransfused. The erythrocyte phenotyping should be systematic to all major sickle cell patients.
\end{abstract}

Keywords: Sickle Cell Anemia, Anti-Erythrocyte Alloimmunization, Transfusion

\section{Introduction}

The management of sickl cell disease often requires the use of blood transfusion. It helps to prevent or treat some complications with a simple blood transfusion or exchange transfusion in an acute setting or during a transfusion protocol in the long term. Its effect is twofold since improves the oxygen-carrying capacity of the blood by raising the $\mathrm{Hb}$ and reduce the harmful effects of $\mathrm{HbS}$ by reducing its percentage in favor of $\mathrm{HbA}$. Transfusion is not with out risk to these patients. The major immunological risk of transfusion is the anti-erythrocyte alloimmunization which can lead to severe immune hemolytic accidents and transfusion dead lock situations. The allo-immunization is a common occurrence to sickle cell disease patients receiving multiple transfusions about 4 to $40 \%$ [1]. Regular immunohematological monitoring is therefore necessary and is an indispensable part of the management of these multiple transfusions. This will create a file for each patient and to know, at anytime, the history of the results of its research irregular antibodies. The lack of knowledge of the history could lead to the attribution of pheno-incompatible red concentrates blood cells which will be at the origin of a hemolytic transfusion accident by reactivation of an infraserological allo-antibody. It is reduced by phenotyped and compatibilized blood transfusion policies to these polytransfused patients [1]. However, the immunological risk 
is increased in general when a transfusion is practiced in emergency, which is often the case in Côte d'Ivoire where the prevalence of carriers of $\mathrm{HbS}$ is $14 \%$ [2]. At the national blood transfusion center (NBTC) in Abidjan, polytransfused patients for hemoglobinopathies are regularly monitored. The aim of our study was to determine the frequency of antierythrocytic allo-immunization to sickle cell patients followed in the transfusion therapeutic unit (UTT) to the NBTC of Abidjan in Côte d'Ivoire in order to propose strategies for strengthening transfusion safety.

\section{Patients and Methods}

We conducted a prospective and descriptive study with systematic inclusion of major sickle cell patients transfused at least once in the transfusion therapy unit of NBTC in Abidjan Côte D'Ivoire from January to December 2013. The study sample consisted of 42 sickle cell patients. Were included in our study the major sickle cell disease $\left(\mathrm{SS}, \mathrm{SC}, \mathrm{S} \beta^{\circ}\right)$ with a transfusion history. We have consistently achieved the $\mathrm{ABO}$ blood group and $\mathrm{Rh}$ Kel phenotype in all patients. Blood groups $\mathrm{ABO}, \mathrm{Rh} 1$ were determined using the plate technique with anti-A, anti-B, anti-AB and anti-D test serum from the BIORAD laboratories. Rh Kel phenotypes were determined by gel filtration technique using DiaClon Rh-Subgroups cards + K (BIORAD, France).

Before and after each transfusion, we performed the search for irregular agglutinin. To do this, the technique of Coombs indirect-low ionic strength gel filtration (Diamed), including a panel of $\mathrm{O}$ red cells type produced at the center and containing the most important regulatory antigens in terms of transfusion safety was carried out.

Panels of three red blood cells for screening and 11 for identification were used.

The patients were transfused with red blood cells compatible in ABO-Rh and Kel.

Data analysis was performed using Epi Info Version 6.4d.

\section{Results}

Table 1. Distribution of patients by age, sex and hemoglobin phenotype.

\begin{tabular}{lll}
\hline Parameters & Number & Percentage \\
\hline AGE GROUP (year) & & \\
{$[0-15]$} & 12 & 28,6 \\
$\geq 16$ & 30 & 71,4 \\
Age mean: 24,45; & & \\
extrêmes: 4-68 & & \\
SEX & & \\
male & 21 & 50 \\
Female & 21 & 50 \\
Sex-ratio1(50/50) & & \\
HEMOGLOBIN PHENOTYPE & & \\
SSFA2 & 32 & 76,2 \\
SFA2 & 9 & 21,4 \\
SC & 1 & 2,4 \\
SAFA2 & 0 & 0 \\
\hline
\end{tabular}

The mean age of the patients was 24.45 years with extremes of 4 years and 68 years. Adults were the majority in $71.4 \%$ of the cases.

There were as many male subjects as female subjects $($ Sexratio=1).

The homozygous phenotype hemoglobin predominated in $76.2 \%$ of the cases.

Table 2. Patients distribution according the ABO blood group.

\begin{tabular}{lll}
\hline Blood Group ABO & Number & Percentage \\
\hline A & 9 & 21,4 \\
B & 8 & 19,1 \\
AB & 2 & 4,8 \\
O & 23 & 54,7 \\
Total & 42 & 100 \\
\hline
\end{tabular}

Just over half of patients (54.7\%) had blood groupO

Table 3. Patients distribution according to the Rh phenotyp Rh Kell.

\begin{tabular}{lll}
\hline Phenotype Rh & Number(n=42) & Percentage \\
\hline Dccee $(\mathrm{D}+\mathrm{C}-\mathrm{E}-\mathrm{c}+\mathrm{e}+)$ & 23 & 54,7 \\
$\operatorname{DccEe}(\mathrm{D}+\mathrm{C}-\mathrm{E}+\mathrm{c}+\mathrm{e}+)$ & 6 & 14,3 \\
$\mathrm{DCcee}(\mathrm{D}+\mathrm{C}+\mathrm{E}-\mathrm{c}+\mathrm{e}+)$ & 6 & 14,3 \\
DCEce $(\mathrm{D}+\mathrm{C}+\mathrm{E}+\mathrm{c}+\mathrm{e}+)$ & 1 & 2,4 \\
$\operatorname{DccEE}(\mathrm{D}+\mathrm{C}-\mathrm{E}+\mathrm{c}+\mathrm{e}-)$ & 1 & 2,4 \\
ddCee(D-C+E-c+e+) & 2 & 4,8 \\
ddccee(D-C-E-c+e+) & 3 & 7,1 \\
Phenotype Kel & Number $(\mathrm{n}=42)$ & Percentage \\
Kel négatif & 40 & 95,2 \\
Kel positif & 2 & 4,8 \\
\hline
\end{tabular}

The phenotype Dccee was most frequently observed in the Rh system (54.7\%) followed by phenotype DCcee (14.3\%) and DccEe (14.3\%).

The majority of patients had negative phenotyp Kel1 $(95.2 \%)$.

Number of transfusions received.

Table 4. Patients Distribution according to the number of transfusions received.

\begin{tabular}{lll}
\hline Number of Transfusion & Number & Percentage \\
\hline 1 & 5 & 11,9 \\
$2-5$ & 11 & 26,2 \\
$6-10$ & 15 & 35,7 \\
$>10$ & 11 & 26,2 \\
TOTAL & 42 & 100 \\
\hline
\end{tabular}

$1 / 3$ patients $(36.1 \%)$ received at least 4 transfusions.

Table 5. Patients distribution according to the presence of irregular antibodies.

\begin{tabular}{lll}
\hline RAI & Number & Percentage \\
\hline Négative & 30 & 71,4 \\
Positive & 12 & 28,6 \\
Total & 42 & 100 \\
\hline
\end{tabular}

The search for irregular agglutinin was positive in $28.6 \%$ of cases. 
Table 6. Patients distribution according to the specific irregular Ac.

\begin{tabular}{ll}
\hline Irregular Antibody* & Number(14) \\
\hline anti-D & 1 \\
anti-C & 4 \\
anti-E & 6 \\
anti-c & - \\
anti-e & 1 \\
anti-K & - \\
anti-S & 1 \\
nonidentify & 1 \\
\hline
\end{tabular}

*A patient may have more than one irregular antibodies: one patient with anti-D + anti-C, another with anti-E + anti-S.

All the antibodies identified (total14) were irregular immune mostly directed against antigens of the Rh system with a predominance of specificities anti-E and anti-C.

\section{Discussion}

The average age of the patients in transfusion program in the therapeutic unit of the NBTC of Côte d'Ivoire was 24.45 years (range: 4 years and 68years). Children (1-15 years) accounted for $28.6 \%$ and $71.4 \%$ adults. These results are superimposed on those of Diarra in Mali who observed an average age of 21 years (range: 1 to 62 years) and children accounted for $32 \%$, adults $68 \%$. [3].

In our study, there was no sex-related predominance (21 female patients and 21 male sex ratio=1). This observation differs from studies conducted by Dembélé in Côte d'Ivoire which reported a sex ratio of 1.02 in favor of the male and Diarra in Mali which observed a female predominance with a sex ratio of 0.73 .

Our patients were predominantly sickle cell homozygous SS $(76.2 \%)$. This would be related to the severity of the disease in this form with the occurrence of acute or chronic complications. Our results are similar to those obtained by Diarra in Mali who obtained $72.2 \%$ of sickle cell anemia [3]. It is these complications that justify the indication of transfusion to these patients.

The distribution of antigens blood group in the $\mathrm{ABO}$ and $\mathrm{Rh}$ systems is comparable with those of previous studies conducted in Côte d'Ivoire [4] and elsewhere in Africa [5]. Infact, in most African series, the $\mathrm{O}$ group (54.7\%) and the positive $\mathrm{Rh}$ group ( $\mathrm{Rh} \mathrm{D}+: 88.1 \%$ ) and the phenotype $\mathrm{Rh}$ Dcece $(54.7 \%)$ are predominantly found. Menier and al. observed in a French study of an Afro-Antillean sickle cell cohort the same distribution of the $\mathrm{ABO}$ and $\mathrm{RH}$ blood groups ( $51 \%$ of O, $93 \%$ of D+ of which $54 \%$ of Dcece) [6].

Regarding the Kell phenotype, the majority of our patients was kell negative (95.2\%). These results corroborate those of Siransy and al. [7] and Sekongo and al. [8].

The frequency of positive RAI was2 8.6\% (12/42). These all immunizations were observed during the initial review of the first track in the UTT. These patients were previously monitored and transfused into other clinical services. This frequency of anti-erythrocytic alloimmunization is far superior to those published in Mali by Diarra in 2011, ie $4.4 \%$ [3] or in Côte d'Ivoire by Malèwe in 2005, ie 4\% [9].
It is close to those reported by Ben Amor in Tunisia in 2009 or 25.9 \% [10], or by Dembélé in Côte D'Ivoire in 2013 ie $26.1 \%$ [11]. In 2008, Akré and al [2] had found a strong immunization of their patients in the order of $62.8 \%$. Their result was comparable to Alarif [12] in 1985 (64\%) and Olulohungbe [13] in 2001(76\%).

In our study, positive RAI were the most observed in patients with transfusions greater than 4 .

Patients enrolled in the long-term transfusion program who were transfused only to the UTT where phenotyping in Rh Kel and had the Laboratory Compatibility Test (EDCL) systematically prior to transfusions, and have not developed anti-Erythrocyte allo-immunisation.

Most of our patients received an average of 9 transfusions with extremes of 1 and 22 transfusions. We could not establish the exact time of immunization of patients transfused outside the UTT. Akre and al. [2] reported in their study immunization from the $4^{\text {th }}$ transfusion. Pinto and al, reported a risk of developing an anti-erythrocyte alloimmunization 16 times higher in patients who received more than ten blood transfusions. [14].

Regarding the specificity of allo-antibodies, 14 antibodies were detected in our patients including 2 cases of association of 2 alloantibodies, mostly directed against antigens of the $\mathrm{Rh}$ system (12 anti Rh against 1 anti-S 1 unidentified and no anti-KEL) with a high prevalence of anti-E, anti-C specificities. The anti-erythrocyte allo-immunization is a relatively rare complication from the systematic use of red blood cell concentrates $\mathrm{Rh}$ Kel phenotyped because the majority of antibody once encountered appear in these [6] systems. This was well illustrated in a Tunisian study of 84 cases of hemoglobinopathies in which Ben Amor and al showed that the alloantibodies were mainly of $\mathrm{Rh}$ phenotype when using standard red blood cells [2]. In this study the specificities were essentially anti-E. With the use of phenotyped red blood cells, the number of alloantibodies was reduced to 3 with anti-FY1 and anti-JK2 specificities. This shows the utility of systematic Rh phenotyping in any sickle cell anemia in reducing the risk of post-transfusional antierythrocytic allo-immunization. Allo-immunization can be expressed either by the acquisition of one or more alloantibodies which will make later transfusions difficult or by an immediate or delayed haemolytic accident [15].

We observed in our study 1 case of RAI positive with posttransfusion haemolysis associated also with hemochromatosis. It maybe associated with autoimmunization which may increase the risk of hemolytic accidents.

\section{Conclusion}

Sickle cell disease is a hemoglobinopathy whose major treatment remains the transfusion of red blood cells. However, this treatment is not without risk. This study shows the high frequency of post-transfusional anti-erythrocytic allo-immunization in sickle cell anemia. The factors influencing anti-erythrocyte alloimmunization mainly 
concern transfused blood products. This requires the implementation of a preventive transfusion strategy to ensure optimal transfusion safety; to know: -transfusion of compatible $\mathrm{Rh} / \mathrm{Kel}$ red blood cells and, if possible, FY JK and MNS;

- Regular immunological monitoring of polytransfused patients by the search for irregular agglutinins and the direct Coombs test.

- patients Informing and health care personnel about transfusion practices during sickle cell anemia and the problems associated with this therapy: alloimmunization can lead to clinical complications to polytransfused patients, including post-transfusion haemolysis, Obstetric future of female subjects.

\section{References}

[1] F.Noizat-Pirenne. Séance éducationnelle. Transfusion et drépanocytose: axes d'optimisation de la sécurité transfusionnelle. Transfus Clin et Biol 2014; 2177-84.

[2] Akré DP, Seka-Seka J. ,Dasse S.R., Kple-Faget P., Hien S., N'Guessan K., Sombo M.F. Recherche d'auto-anticorps antiérythrocytaires dans un échantillon de patients drépanocytaires suivis au CHU de Cocody-Abidjan. Rev.I nt. Méd. 2008; 10(3): 7-12.

[3] A.B. Diarra, A. Guindo B, B. Kouriba, A. Dorieb, D.T .Diabaté, S.I. Diawara, et al. Sécurité transfusionnelle et drépanocytose à Bamako, Mali: Séroprévalence de l'infections à VIH, VHB, VHC et allo-immunisation anti-Rh et Kell chez les drépanocytaires Transfusion Clinique et Biologique 2013; 20: $476-81$.

[4] Centre National de Transfusion Sanguine, Abidjan, Côte d'Ivoire. Rapport d'activités 2012.

[5] Tayou C, et al. Le phenotype érythrocytaire dans le système $\mathrm{ABO}-\mathrm{Rh}$ chez le donneur et le receveur de produits sanguins dans le milieu hospitalier camerounais: adapter l'offre à la demande. Rev Med Brux 2009;30: 145-216.

[6] N. Meunier, M. Rodet, P. Bonin, P. Chadebech, B. Chami, K. Lee, et al. Étude d'une cohort de 206 patients drépanocytaires adultes transfusés: immunisation, risqué transfusionnel et resources en concentrés globulaires. Transfus ClinBiol 2008; 15: $377-82$.

[7] Siransy-Bogui L., Dembele B., Sekongo Y., Abisse S., Konaté S., and Sombo M. Phenotypic Profile of Rh and Kell Blood Group Systems among Blood Donors in Cote d'Ivoire, West Africa. Hindawi Publishing Corporation Journal of Blood Transfusion 2014, ID 309817: 4p.

[8] Sekongo Y. M., Kassogue K., Kouamenan G. S., Konan S., Kouassi P, Lagou A.D., Kouacou-A.P., Konate S, Abisse A.. Mapping of Blood Group and Erythrocyt Phenotyp Rhesus and Kell to Sickle Cell Desease Patients in Transfusion Program in the Therapeutic Unit of the National Blood Transfusion Center (NBTC) of Abidjan Côte d'ivoire. International Journal of Immunology. 2015,4; 3: 47-51.

[9] Maléwé K. Allo-immunisation anti-érythrocytaire posttransfusionnelle chez les drépanocytaires majeurs: etude primaire. Thèse, Med Abidjan, UFR des Sciences Médicales 2005: No 1249.

[10] I. Ben Amor, N. Louati, H. Khemekhema, A. Dhieb, H.Rekik, M. Mdhaffar, et al. Immunisation anti-érythrocytaire dans les hémoglobinopathies: à propos de 84 cas Transfus Clin Biol 2012;19: 345-52.

[11] Dembélé. A. Allo-immunisation anti-érythrocytaire posttransfusionnelle chez les drépanocytaires. Mémoire hématologie, Med Abidjan, UFR des Sciences Médicales 2013.

[12] ALarif. L, Castro O, Ofusu Metal. (1986) HLA B35 is associated with red cell alloimmunization in sickle cell disease. Clin. Immunol. Immunopath.; 38(2): 178-83.

[13] Olujohungbe A, Hambleton I, Stephens L, Serjeant B et Serjeant G (2001) Red cell antibodies in patients with homozygous sickle cell disease: a comparison of patients in Jamaica and the United Kingdom. Br J Haematol.; 113 (3): $661-5$.

[14] Pinto PC, Braga JA, Santos AM. Risk factors for alloimmunization in patients with sickle cell anemia. Rev Assoc Med Bras 2011; 57: 668-73.

[15] C. Boulat. La transfusion du drépanocytaire Transfus Clin Biol 2013; 20: 68-71. 